\title{
Completeness criteria and filling of medical records in dental clinic of Cianjur General Hospital (January - April 2011)
}

\author{
Annisa Rosalina *, Netty Suryanti *, Riana Wardani * \\ *Department of Dental Public Health Faculty of Dentistry Universitas Padjadjaran
}

ABSTRACT

Introduction: The medical record documentation of patient treatment Provides the which in turn, must be maintained Clearly, concisely, comprehensively and accurately. Medical record and its filling criteria must be based on the regulation of the Minister of Health of The Republic of Indonesia No. 269/Menkes/Per/III / 2008 regarding to the medical record. The research was Aimed to unveil the completeness of both criteria and filling on medical records at the General Hospital's Dental Polyclinic of Cianjur District. Methods: Survey-based descriptive method was applied within the research. Its Data was acquired through the examination on medical records and interviews. Random sampling was conducted to run the sampling technique. 89 pieces of outpatient's medical records were embodied as samples. Results: Based on the research results, it is discovered that 6 out of 12 criteria (50\%) are not listed within the medical record. Thus, the filling on medical records of $100 \%$ is found incomplete. Conclusion: Medical records Dental Clinic Regional General Hospital Cianjur according to standards Permenkes No. 269/2008 not inlude on complete criteria according to standards Permenkes No. 269/2008.

Keywords: Medical records, dental polyclinic, hospital.

\section{INTRODUCTION}

One of the objectives of national development is the development of the health sector, namely, to achieve a healthy life for every resident to realize optimal health status. One of the development efforts in the health sector is the construction of various health-care facilities such as hospitals, health centres, clinics, physician practices and other others. ${ }^{1}$

The health care facilities serve as a means of socialization, prevention, treatment and rehabilitation. Health care facilities also serve as improving both mental and physical health that was held as places medicine or dental practice. ${ }^{2}$
One of the main elements in excellent health services system is the availability of medical services by doctors and dentists, the quality is maintained in according to the mandate of Law Number 29 the Year 2004 regarding Medical Practice. Every doctor and dentist shall comply with the standards, guidelines, and procedures that apply in the administration of medical practice so that people receive professional and safe in medical services. One of the regulatory function in the Law of Medical Practice is the regulation of the medical record which are article 46 and article $47 .^{2}$

The medical record is a written evidence of the services provided by doctors and dentists. 
Medical records containing clinical data of patients during the process of diagnosis and treatment. Every medical service activities must be recorded in medical records with a complete and accurate data for each patient, and each doctor/dentist must complete medical record correctly, complete, and timely. ${ }^{3}$

The purpose of the medical record is to support in achieving orderly administration in the context of efforts to improve hospital services. Hospital orderly administration would not work as expected without the support of a medical record management system which was done accurately. Orderly administration is one of the factors that determine health services in hospitals. ${ }^{4}$

One of the health services at the hospital is dental and oral health services. Oral health requires correct, complete, and accurate medical records in order to improve hospital services. Medical records in the dental field are recently very important, for example, in the present circumstances which are rife with disasters and the threat of terrorism that occurred in Indonesia lately. Medical records in the dental field are essential because of the experience in the event of a mass disaster. The role of the dentist is important in the identification of the dead victims. Teeth are one of the means of identification that can be trusted, especially when the data of medical records and $\mathrm{x}$-rays teeth tooth during life were stored properly). ${ }^{5}$ Complete medical record by medical personnel would facilitate other health professionals in delivering the action or therapy to the patient. The medical record, as well as a data source, will be useful information for management in determining the strategic steps for the development of health services. ${ }^{6}$

The main problems and obstacles in the implementation of the medical records of doctors and dentists are not fully aware of the benefits and uses of medical records, both on health care facilities and in individual practice, as a result of medical records made incomplete, unclear, and not timely. Medical records are crucial in analyzing a case as with definitive evidence. The references for organizing medical records of medical practice relating to the aspects of the law will be applied tp needed health care facilities. ${ }^{3}$

The standard criteria for the medical record and the data recorder are complete, accurate and timely and in accordance with Permenkes number RI 269 / Menkes / Per / III / 2008. Some of the results of previous studies about the completeness of the medical record, as was done in the Hospital Cibabat Cimahi and Hospital PINDAD Bandung, stated that the filling of medical records at the dental clinic is not complete. The research results show the organization of medical records at the hospital is not in accordance with Permenkes No. 269/Menkes / Per / III / 2008. This prompted the authors to do further research on the completeness of the medical record at one of the public hospitals at the other areas as one of the health care facilities that exist in other areas of Indonesia, namely the Regional General Hospital in Cianjur, given the regulation's health minister has conducted since 2008.

Regional General Hospital Cianjur, hereinafter known as RSUD Cianjur, is one of the general hospital in Indonesia, located in the district of Cianjur. In line with efforts to develop and improve the quality of service after going through the review and assessment of the fulfillment of class standards Hospital by the Ministry of Health in 2004, hospitals Cianjur increased class level into Class B Non Hospital Education with seventeen specialist services. In these hospitals the socialization of medical records by Ministry of Health Republic of Indonesia No. 269 / Menkes / Per / III / 2008 have been applied concerning the medical record that contains the latest provisions regarding the completeness of the medical record since the regulation was issued in 2008 .

Based on the above, the authors wanted to find out and try to examine the completeness criteria and filling medical records of outpatient in Dental Polyclinic and RSUD Cianjur, as the objective of this study is to gain insight about the completeness criteria and filling of medical records at the Dental Polyclinic and RSUD Cianjur.

\section{METHODS}

The type of research is descriptive with the survey method. Descriptive is a method of research conducted with the main objective to create a picture or a description of a situation objectively. ${ }^{7}$ The population in this research is an outpatient medical record, which came as a new patient at the Dental Clinic and RSUD Cianjur in 
January-April 2011. The sampling technique used was simple random sampling. Simple Random Sampling is sampled chance (probability sampling), where their researchers select the sample gave an equal opportunity to all members of the population so that the results can be evaluated objectively. ${ }^{8,9}$ The number of samples are taken using sampling techniques and formulation of Notoatmodjo (2010), and 89 medical records were obtained. Eighty-nine samples taken randomly from the medical records of outpatients come as new patients in January-April 2011.

\section{RESULTS}

The medical records of outpatients in the Denta Clinic and RSUD Cianjur are in the form of folder containing multiple columns identities of the patients who required when the patient first came as a new patient and a card in it that contains a column of a patient's identity, the date, the main complaint, diagnosis, treatment and doctor's signature.

The medical records of outpatients in hospitals Cianjur is filled by the registration officer and health workers. Filling the identity of the patient on the map and on a piece of paper is made by the registration officer in the registration room when the patient first came to hospitals Cianjur as a new patient. The patient's medical data is done by a dentist in the dental treatment room.
Sub-Sector Data and the medical record RSUD Cianjur is a unit that is responsible in terms of the organization of medical records. Medical record distribution process flow starting from reception for patients assigned to receive patients and then part of medical records processing, storage and eventually to the data compilation and reports. The research results for the medical records of outpatients come in as a new patient to the Dental Clinic, and RSUD Cianjur in January April 2011 are presented in tables 4.1 and 4.2. The results are analyzed and will be presented by an analysis of the frequency distribution in which all the research data are tabulated by calculating the frequency distribution.

Completeness of medical records criteria for outpatient Dental Clinic and RSUD Cianjur can be seen in Table 1, where it appears that there are several criteria for medical records according to Minister of Health Regulation No. 269/ Menkes / $\mathrm{Per} / \mathrm{III} / 2008$, which is not included in the medical record sheet outpatient Dental Clinic and RSUDI Cianjur. Such criteria, namely: the creation time field status, physical examination and medical support, plan of management, odontogram and informed consent.

Completeness of medical records outpatient Dental Clinic and RSUD Cianjur can be seen in Table 2. Criteria for patient identity data in Table 2 (a) it shows that the data required were filled completely in the medical record with the file number, name, gender, date of birth/age, and

Table 1. Distribution frequency medical record completion criteria for the details outpatient medical record

\begin{tabular}{|c|c|c|c|}
\hline & \multirow[t]{2}{*}{$\begin{array}{l}\text { Format criteria outpatient medical records according to } \\
\text { Permenkes No. } 269 \text { of } 2008\end{array}$} & \multicolumn{2}{|c|}{$\begin{array}{l}\text { Format criteria medical records outpatient Denta } \\
\text { Polyclinic Hospital Cianjur }\end{array}$} \\
\hline & & listed & Not listed \\
\hline a & Patient Identity When Necessary & s & - \\
\hline \multirow{2}{*}{ b } & date & s & - \\
\hline & Time & - & r \\
\hline c & Results anamnesis & r & - \\
\hline \multirow{2}{*}{ d } & Physical examination & - & r \\
\hline & Supporting investigation & - & s \\
\hline e & diagnosis & s & - \\
\hline$f$ & Management plan & - & r \\
\hline g & Treatment and / or actions & ऽ & - \\
\hline $\mathrm{h}$ & Other services that have been given to patients & s & - \\
\hline i & Odontogram & - & r \\
\hline j & Informed Consent & - & J \\
\hline
\end{tabular}


Table 2. For details completeness of medical records medical record data writing outpatient dental clinic and rsud cianjur

\begin{tabular}{|c|c|c|c|c|c|}
\hline & Criteria & Filled & $\%$ & Unallocated & $\%$ \\
\hline \multirow[t]{9}{*}{$\mathrm{a}$} & Patient identity & & & & \\
\hline & file number & 89 & 100 & 0 & 0 \\
\hline & Name & 89 & 100 & 0 & 0 \\
\hline & Gender & 89 & 100 & 0 & 0 \\
\hline & TTL / Age & 89 & 100 & 0 & 0 \\
\hline & Address & 89 & 100 & 0 & 0 \\
\hline & No. tel / hp & 0 & 0 & 89 & 100 \\
\hline & Profession & 0 & 0 & 89 & 100 \\
\hline & Office address & 0 & 0 & 89 & 100 \\
\hline \multirow[t]{3}{*}{ b } & Date and Time & & & & \\
\hline & date & 89 & 100 & 0 & 0 \\
\hline & Time & 0 & 0 & 89 & 100 \\
\hline c. & Results History & 11 & 12.36 & 78 & 87.64 \\
\hline \multirow[t]{3}{*}{ d } & Physical examination and & & & & \\
\hline & Physical examination & 0 & 0 & 89 & 100 \\
\hline & Supporting investigation & 89 & 100 & 0 & 0 \\
\hline e. & diagnosis & 89 & 100 & 0 & 0 \\
\hline f. & Management plan & 10 & 11.24 & 79 & 88.76 \\
\hline g. & Treatment and / or Action & 89 & 100 & 0 & 0 \\
\hline h. & Other services be given & 89 & 100 & 0 & 0 \\
\hline i. & Odontogram & 0 & 0 & 89 & 100 \\
\hline j. & Informed Consent & 67 & 75.28 & 22 & 24.72 \\
\hline
\end{tabular}

address, while telephone number, occupation and address of the office all the data has not been completed.

On the status creation date criteria, Table 4.2 (b), all fully completed, while the criteria for creation time status on all medical records have not been completed. On the outcomes anamnesis, Table 2 (c), the data is not complete in the amount of 78 pieces of medical records (87.64\%) and full data for 11 pieces of medical records (12.36\%). On physical examination criteria, Table 4.2 (d) $100 \%$ has not been completed, and the data results of investigations totalling 89 pieces complete medical record $(100 \%)$.

In the diagnostic criteria, Table 2 (e), the data is fully completed at the medical records of 89 pieces $(100 \%)$. In the management plan criteria, Table 2 ( $\mathrm{f}$ ), which is not complete in the amount of 79 pieces of medical records $(88.76 \%)$ and data management plan for ten pieces complete medical record (11.24\%).

On the criteria for treatment and/or action, Table 2 (g), Completed on 89 pieces of medical records (100\%). On criteria, other services have been given to patients, Table 2 ( $h$ ), fully completed at the medical records of 89 pieces $(100 \%)$.

At the clinic odontogram criteria, Table 2 (i), has not been completed totalling 89 pieces of the medical record $(100 \%)$. In the act of approval criteria, Table $2(\mathrm{j})$, which is not complete at 22 pieces of medical records $(24.72 \%)$ and the data consent of 67 pieces complete medical record (75.28\%).

\section{DISCUSSION}

The medical record is the file containing the records and documents on identity, examination, treatment, action, and other services (provided) to the patient (used and available) on health care facilities. ${ }^{10}$

Hospital medical record is an important component in the implementation of management activities in the hospital. The medical record must be able to provide complete information about the medical and health services in hospitals. ${ }^{11}$ 
Research in Dental Clinic of RSUD Cianjur on the medical records of outpatient about the completeness of the criteria listed in the medical record format is presented in Table 4.1. It can be seen that the criteria in the medical record are still incomplete accordance with the standards of the Ministry of Health Regulation No. 269/Menkes / Per / III / 2008. There are several criteria not listed in the medical record, which are the time of making status, physical examination and medical support, plan of management, odontogram and informed consent as all the criteria are very important and must be filled out completely.

The state of some of the criteria that are not listed in the medical record that causes the charging criteria, not in place, such as the results of medical investigations are seen filled in the treatment column and management plan is filled in the column of major complaints or outcome history.This matter is not in accordance with the Regulation of the Minister of Health of the Republic of Indonesia No. 269 / Menkes / Per / III / 2008 concerning the Medical Record which stated that the contents of the medical records should contain at least the patient's identity, date and time, the results of history taking, physical examination and medical support, diagnosis, treatment planning, treatment and / or actions, other services have been given to patients, patients odontogram, and the informed consent. Research results in RSUD Cianjur presented in Table 4.2 where the completeness of the medical records of outpatient dental clinic can be seen that from the 89 files of medical records, it was found that the criteria for patient identification 4.2 (a), especially patients telephone number, occupation and address of the office $100 \%$ no fully recorded, even all three criteria have been listed in the medical record. According to one staff member of the Medical Records in RSUD Cianjur, incomplete filling of patient's identity is due to lack of human resources in the registration section at outpatient installation, whereas patients who come every day were pretty much, so the registration officer did not have enough time to fill out the identity of the patients completely. Patient identification data such as phone numbers, occupation and address of the office is a very important data, where the purpose of collecting this demographic information is to fully inform the patient's identity. The importance of such things as described by Hatta, that the hospital and healthcare-related organizations also use the patient demographic information as the basis of statistical data, research and resource planning. Generally, administrative data is identification data that can be associated with patients (patient-identifiable information) that is used for administrative purposes, regulatory, operational, health care and reimbursement of healthcare costs.

Information on the date and time criteria for patient visits, Table 2 (b), in all of the medical records the description of dates is $100 \%$ completed while visiting time for the patient has not $100 \%$ completed. This was due to the inclusion criteria of the time, Table 1 (b), in the medical record. The medical record must be assembled and equipped entirely by doctors, nurses, midwives and medical personnel. Every action performed on the patient's consultation, the latest medical records is required within $1 \times 24$ hours. All registration must be signed off by a doctor or other health worker and write down the exact name and dated. ${ }^{12}$

The results showed that most of the medical records on outcomes anamnesis, Table 2 (c), 78 of the medical records $(87.64 \%)$ had not been completed, and 11 of medical records (12.36\%) filled out completely. The result from interviews, incompleteness is due to insufficient time for the dentist to complete the anamnesis results because of the number of patients who come in each day reaching 20-30 people, while the dentist only two people.

In addition to the above, incomplete anamnesis results also caused by a dentist who considers the anamnesis is not important and does not affect the enforcement of diagnosis or patient management plan according to Pamungkassari history. The results of anamnesis are very important, as revealed by Kurtiyono ${ }^{13}$ that errors in diagnostic can be caused by doctors who consider medical history does important. Thus it is not recorded in the medical record. ${ }^{13}$

The entire medical record $(100 \%)$, the criteria results of the supporting examination was filled completely, but the results of a physical examination criteria, Table 2 (d), has not been completed. Incomplete filling for criteria of physical examination due to these criteria was 
not listed in the medical record sheet, as shown in Table 1 (d).

The physical examination should be performed by a doctor to avoid inaccurate information and prevent misdiagnosis due to negligence in the clinical examination. The series of examination by Grossman et al. ${ }^{14}$ must be recorded in the patient chart and should serve as a guide to make the right diagnosis. Physical examination is very important according to Willms et al. ${ }^{15}$ in determining the diagnosis and treatment planning for the patients.

In the diagnostic criteria, Table 2 (e), as many as 89 medical records $(100 \%)$ filled out completely. The treatment will be effective if the diagnosis is done carefully and accurately. ${ }^{16}$

In the management plan criteria, presented in table 2 (f), as many as 10 medical records (11.24\%) filled completely and as many as 79 medical records $(88.76 \%)$ has not been completed. This criterion was not included in the medical record, shown in table 1 (f), so that the doctor can not fill these criteria. This management plan is important as described by Rustiyanto, as a basis for planning the treatment / management should be given to the patient.

A total of 89 medical records (100\%), completely filled in for treatment and / or action, is presented in Table 2 (g). Recording of the treatment given to patients is very important to monitor and assess the course of treatment and could change the treatment if necessary.

A total of 89 medical records $(100 \%)$ Completed on criteria other services provided to patients, is seen in table $2(\mathrm{~h})$. Another important service to patients filled to know the disease who have or are sustained and treatment history that ever lived.

The entire medical record $(100 \%)$, has not been completed at the clinic odontogram criteria shown in Table 2 (i), this is because the doctor thinks odontogram not so important.

Moreover, according to one of the staff at the Dental Polyclinic Hospital Cianjur, stating that it had been the last few months odontogram sheet is not available, because it is not provided by the hospital. Yet according to the Ministry of Health of the Republic of Indonesia No. 269/Menkes/ Per/III/2008 concerning the medical record, in a medical record shall include the completeness of the odontogram special clinic for dental patients. Odontogram important to make dental treatment plan thoroughly and very valuable as the necessary data for the purposes identifikasijika any time. ${ }^{5}$

Research shows approval of medical action is not filled completely, in table 2 ( $\mathrm{j}$ ) shows as many as 22 medical records (24.72\%), while the completed medical records were $67(75.28 \%)$. It is caused by a sheet of consent that is not integrated with the medical record sheet, so that the sheet can be separated and lost from the medical record. Doctors also sometimes do not know the importance of informed consent, so it was not necessary to fill it when the doctor must get approval from the patient or a person authorized before performing medical procedures on a patient's self. Approval was given after doctors provide sufficient information to the patient or a person authorized. ${ }^{17}$

Results of research for the completeness of medical records showed incomplete, because the criteria contained in the medical record but has not been completed. Such criteria are criteria for the phone number of the patient, the patient's occupation, the office address of the patient and the results of the anamnesis.

Besides charging is not complete, because the criteria are not listed in medical records in hospitals Cianjur but there are some who filled in another column. The criteria are that the management plan, the results of the medical support, and approval of any necessary action.

Other criteria that are not complete, because the criteria are not listed in medical records in hospitals Cianjur and has not been completed, the criterion is the time, physical examination and clinical odontogram.

Head of Hospital Medical Records Cianjur stated that he had been socializing on Permenkes RI no. 269 of 2008 on medical records to the entire staff of medical records and health workers when the regulation was issued, namely in 2008.

Although socialization has been done, but the filling of medical records are still incomplete. This is because the number of patients coming to the hospital outpatient installation Cianjur, especially in the dental clinic can be reached 2030 patients per day, so that health workers in this case a dentist who only amounted to two people do not have enough time to fill Detailed medical 
records.

Additionally incomplete filling of medical records caused by the 6 criteria in the medical record that has not been mentioned, so it does not meet the standards that have been set as the Minister Regulation No. 269 of 2008. The results of interviews with one of the staff section of data and medical records stated that the lack of warning or supervision from superiors and from the

Medical records committee of the health workers who do not fill out a complete medical record, the cause of the organization of medical records in hospitals Cianjur incompatible with Permenkes No. 268/2008.

\section{CONCLUSION}

Medical records Dental Clinic Regional General Hospital Cianjur according to standards Permenkes No. 269/2008 not inlude on complete criteria according to standards Permenkes No. $269 / 2008$.

\section{REFERENCES}

1. Fauzi. Medical Record Retention. Available from: http://id.shvoong.com/medicineandhealth/epidemiology-public-health/1881033retensi-rekam-medisbab/. It 1. [Cited 20 March 2011). 2009.

2. Medical Practice Act. Article 46 Paragraph 1 of the Medical Record. Jakarta: Indonesian Doctors Association. 2004. p. 5

3. Indonesian Medical Council. Manual of Medical Records. Jakarta: MOH. 2006. p. 1,3,6,10-11.

4. Rustyanto E. Medical Record and Health Information. Yogyakarta: Graha Science. 2009. p. 5-7.

5. Directorate General of Medical Services.
National Standards of Medical Record Dentistry. Jakarta: Ministry of Health. 2004. p. 3-6, 9 .

6. Suhartanto. Making Medical Record Information System at PKU Muhammadiyah General Hospital in Bantul. Yogyakarta: Gadjah Mada University. 2007.

7. Notoatmodjo S. Health Research Methodology. Jakarta: PT. Rineka Reserved. 2005. p. 30

8. Kountur, Ronny. Methods for Writing Thesis and Thesis. Revised Edition. Jakarta: PPM. 2007. p. 108, 148.

9. Singarimbun M, Sofian E. Metode penelitian Survei. Revised Ed. Jakarta: LP3ES. 2008. p. 156.

10. Regulation of the Minister of Health of the Republic of Indonesia No. 269/Menkes/Per/ III/2008 on the Medical Record. Jakarta: $\mathrm{MOH}$. 2008. p. 5.

11. AnwarA. Introduction to HealthAdministration. Jakarta: PT. Bina Arts Literacy. 1996. p. 1.2.

12. Ministry of Health. Handbook of Medical Records Implementation. Jakarta: 1989.

13. Kurtiyono. Forgotten 2009. Medical Record. Dentistry article. South Sulawesi Police. It 45, 47.

14. Grossman LI. Ilmu endodontik dalam praktek. $11^{\text {th }}$ ed. Alih Language: Rafiah Abyono. Jakarta: EGC. 1995.

15. Willms, Janice L. Diagnosis and Evaluation of Physical Function in Ward. Jakarta: EGC. 1994.

16. Walton, Richard E, Torabinejad. Principles and Practice of Science Endodonsia. Interpreter, Narlan Sumawinata; editor of the Indonesian edition, Lilian Sudarsono. Jakarta: EGC. 2008. p. 585.

17. Regulation of the Minister of Health. 1989. Medical Record. Jakarta: MOH. 1989. p. 2. 